\title{
Dificuldades e importância da reprodução do guepardo (Acinonyx jubatus) em cativeiro: Revisão
}

\author{
Anna Claudia Baumel Mongruel ${ }^{1}$ \\ ${ }^{1}$ Universidade Estadual do Centro-Oeste, Campus CEDETEG, Departamento de Medicina Veterinária, Guarapuava, \\ Paraná. [annaclaudiamongruel@gmail.com]
}

ISSUE DOI: $10.3738 / 1982.2278 .1127$

Todos os membros felídeos selvagens encontram-se ameaçados de extinção. Técnicas de conservação in situ e ex situ são utilizadas para aumentar a eficiência reprodutiva e criar reservas genômicas dessas espécies, inclusive do Guepardo (Acinonyx jubatus), que há anos sofre diminuição em sua população de vida livre. O objetivo desse trabalho é reunir informações sobre o comportamento reprodutivo de felídeos silvestres, em especial o Guepardo, descrevendo técnicas de conservação, assim como apontar os erros comuns de manejo e problemas típicos que tornam esse animal um dos mais difíceis de obter sucesso reprodutivo quando cativos. As particularidades reprodutivas de cada espécie são definidas através da ampla diversidade das mesmas e suas localizações demográficas. Felídeos de vida livre possuem a sazonalidade reprodutiva dependente, principalmente do fotoperíodo e da disponibilidade de alimentos. Sob o ponto de vista evolutivo, os processos de ovulação espontânea ou induzida relacionam-se, entre outros fatores, com o grau de sociabilidade das espécies. Felinos que possuem hábitos solitários necessitam de períodos de estro mais longo, assim como a viabilidade de seus oócitos, para que a ovulação ocorra após o encontro de casais na natureza. Muitos fatores exercem influência negativa na reprodução natural desses animais, entre eles são citados: estresse, doenças infecciosas/parasitárias, alterações genéticas e comportamentais, deficiências nutricionais e recintos inapropriados. O distresse, estresse crônico de animais de cativeiro, ocorre quando o indivíduo necessita desviar recursos energéticos de funções biológicas normais para enfrentar a situação estressante, gerando efeitos adversos na reprodução. Tanto em vida livre quanto em cativeiro, guepardos demonstram uma baixa variedade genética, podendo causar impactos negativos em suas funções reprodutivas e sobrevivência a longo tempo. A reprodução em vida livre ainda parece ser alta, com $80 \%$ dos adultos procriando durante seu período de vida. Em cativeiro, esse espécime demonstra dificuldade em se reproduzir. Apenas um terço de todos os zoológicos que mantém guepardos já obtiveram sucesso na reprodução desses animais, sendo a mortalidade de filhotes alta, entre 30-40\%, devido principalmente à negligência materna. Zoológicos acabam por juntar fêmeas de guepardos, naturalmente animais solitários, em pequenos grupos, gerando situações de dominância que causam uma supressão ovariana em fêmeas subordinadas. Essa situação só é revertida e a fêmea só volta a ciclar normalmente quando 
isolada. Fêmeas com altas prioridades à serem reproduzidas devem ser mantidas sozinhas para evitar esse distúrbio. Animais não expostos à reprodução possuem influência de ciclos flutuantes de concentrações de estrógenos, comprometendo órgãos reprodutivos e esgotando mais rapidamente os oócitos, resultando em uma infertilidade precoce desses animais. Estudos encontraram um alto número defeitos primários e secundários de células espermáticas de guepardos, com suspeita que sejam consequências do estresse causado pelo cativeiro nesses animais. Apesar de guepardos machos cativos apresentarem um maior volume espermático, sua concentração é menor do que animais de vida livre, porém todos os guepardos apresentam a condição de teratospermia, característica geralmente genética desses animais.

Palavras-chave: cheetah, felinos, conservação. 